\title{
THE EXCRETION OF INULIN, XYLOSE AND UREA BY NORMAL AND PHLORIZINIZED MAN ${ }^{1}$
}

\author{
By JAMES A. SHANNON AND HOMER W. SMITH \\ (From The Department of Physiology, New York University College of Medicine, \\ New York City)
}

(Received for publication February 13, 1935)

There is now considerable evidence that simple carbohydrates are not secreted in significant quantities by the renal tubules of the vertebrates. This evidence is direct and unequivocal in the case of the aglomerular fish; inability to excrete glucose has been demonstrated in Lophius and Opsanus, and lactose in Opsanus, by Marshall (1930, 1934); xylose is not excreted by Opsanus (Jolliffe (1930)), nor by Lophius from plasma concentrations ranging as high as $400 \mathrm{mgm}$. per cent (Clarke and Smith (1932)); nor is sucrose excreted by this fish from plasma concentrations ranging as high as $1060 \mathrm{mgm}$. per cent (Smith, (1935)). To this evidence may be added the more recent observations that both Lophius and Opsanus are incapable of secreting the polysaccharide inulin (Richards, Westfall and Bott (1934); Shannon (1934b)). In other animals, including the mammals, the evidence against secretion of carbohydrates is indirect. In the normal glomerular dogfish, the simultaneous clearances of xylose and sucrose are identical within the error of the experimental methods used for the determination of these sugars (Shannon $(1934 a)$ ), while in the phlorizinized dogfish these clearances agree with the simultaneous glucose clearance (Clarke and Smith (1932); Shannon $(1934 a))$. Investigators in this laboratory have repeatedly found in the normal dog that the simultaneous clearances of xylose and sucrose (and, in a limited series of observations, raffinose) are essentially identical (Jolliffe, Shannon and Smith $(1932 a, 1932 b)$; Shannon, Jolliffe and Smith (1932) ; Pitts (1933, 1934), and Shannon, quoted by Smith (1935)), although this close identity has not been observed by White and Monaghan (1933) in the dog, nor by Cope (1933) in the rabbit. The simultaneous clearances of

1 The experimental observations recorded here are entirely the contribution of the junior author, and are offered in partial fulfillment of the requirements for the degree of Doctor of Philosophy. xylose and sucrose in normal man differ, according to Keith, Power and Peterson (1933), by 12 per cent, and according to Chasis (see Smith (1935)) by 8 per cent. In phlorizinized man the glucose, xylose and sucrose clearances agree within a few per cent (Chasis, Jolliffe and Smith (1933)). If we postulate secretion of any detectable fraction of these substances, coincidence would have to be invoked to explain the identity of clearances in normal animals. And a further and still less probable coincidence would have to be invoked to explain why phlorizin brings the glucose clearance up to essential identity with the clearances of the non-metabolized sugars in forms showing such diverse renal function as dogfish, dog and man.

We fully recognize the inadequacy of reasoning from the aglomerular fish to the mammal (even excluding the cogent bearing of that evidence upon the dogfish), but when we combine this evidence with the evidence available in normal and phlorizinized dog and man, we believe the conclusion is well justified that the mammalian kidney is no more able to secrete these substances than is the aglomerular fish kidney. (Whether substances containing a carbohydrate complex behave in a manner similar to the simple carbohydrates is under investigation.) It is recognized, however, that the reasoning is inferential; it is possible that coincidence is operative in the normal animal with respect to the excretion of xylose, sucrose and raffinose, and that phlorizin, while blocking the secretion of xylose and sucrose, blocks at the same time the reabsorption of glucose and raises the clearance of this substance to the glomerular level. (Changes in absolute clearance before and after phlorizin constitute an untrustworthy basis for argument in this problem, since this drug is apt to produce changes in renal activity affecting all clearances.)

But whatever view one takes of the matter of secretion, the question of a possible active re- 
absorption and, more particularly, of a possible passive diffusion of substances of low molecular weight across the tubules (especially at high $U / P$ clearance ratios) are not excluded by the above evidence as satisfactorily as might be. Jolliffe, Shannon and Smith (1932a) were led to believe that there was neither active nor passive reabsorption of xylose, sucrose and raffinose by the identity of the simultaneous clearances of these substances in the normal animal, and the relative constancy of these clearances with respect to the urea clearances before and after phlorizin.

It was principally with this question of possible reabsorption in mind, and prompted by the above view regarding the probable non-secretion of carbohydrates, that we extended our investigations to the substance reported on here, namely, inulin. A preliminary report on the excretion of inulin in the dog has been made by Richards, Westfall and Bott (1934). They find that this substance is not excreted by the aglomerular kidney of Opsanus, whereas when injected intravenously into the dog it is excreted rapidly and completely, and in approximately the same ratio to its concentration in the plasma as is creatinine. They observe that the xylose clearance is lower than the simultaneous inulin clearance. Professor Richards, in his recent Harvey Lecture (January 17, 1935), reported further that inulin injected into the frog is excreted in the glomerular urine at the same concentration as it is present in the plasma; that it appears to be completely filterable; and that it is not excreted by the frog's kidney when supplied only to the tubular and not to the glomerular circulation. A report on the excretion of inulin in the dogfish has been made by Shannon (1934b), who has found that the xylose clearance is consistently lower than the simultaneous inulin clearance (averaging 78 per cent of the latter) in the normal animal, and equals the latter in the phlorizinized animal.

Inulin is a polysaccharide, widely distributed as a reserve material in many plants, which on hydrolysis yields fructose. The molecular weight of the unhydrated compound is variously given from 972 to 4860 (Pringsheim (1932)) and is possibly nearer to the latter figure (Irvine and Montgomery (1933); Drew and Haworth (1928); Haworth, Hirst and Percival (1932)), although the available evidence indicates that scission occurs very readily at elevated temperatures.

The inulin used in these experiments, obtained from Pfanstiehl Chemical Company, is a white and presumably pure preparation having a negligible reducing power. It dissolves in 0.6 per cent $\mathrm{NaCl}$ at $85^{\circ} \mathrm{C}$. to the extent of 20 per cent by weight and remains in solution long enough when cooled to $40^{\circ} \mathrm{C}$. to permit intravenous infusion. It is not bound by plasma portein and is diffusible through a collodion membrane (Shannon (1934b)).

Experiments on the dog will be published elsewhere, the present paper being concerned with the simultaneous clearances of inulin, xylose, urea and glucose in normal and phlorizinized man.

\section{EXPERIMENTAL PROCEDURE}

Prior to this work inulin had not been administered parenterally to humans, and for this reason, after extensive experiments on the $\mathrm{dog}$, an intravenous infusion of 160 grams was taken by one of the investigators (J. A. S.). There were no objective or subjective disturbances, nor have any ill effects been observed to follow intravenous infusion into a number of individuals since that time. ${ }^{2}$ The observations reported here were made on seven volunteer convalescent patients from the wards of the Medical Service of the Third (New York University) Medical Division of Bellevue Hospital, with apparently normal renal function. They were chosen on the basis of history, ability to concentrate urine to a specific gravity above 1.030, absence of albumin and a normal urinary sediment.

The inulin was dissolved in sterile 0.6 per cent $\mathrm{NaCl}$ (20 grams to each $100 \mathrm{cc}$.) by heating to a temperature of $85^{\circ} \mathrm{C}$. The resulting solution was invariably clear and had a faint yellow tint. On cooling to $40^{\circ} \mathrm{C}$. recrystallization does not take place for some time, but the solution for injection was prepared just prior to use to prevent the necessity of a second heating. One hundred grams of inulin as given here yield a blood concentration starting at 300 to $400 \mathrm{mgm}$. per cent, and falling to $100 \mathrm{mgm}$. per cent during the next 1.5 to 3 hours.

Schering-Kahlbaum's phlorizin was recrystallized according to the method of Deuel and Chambers (1925). This was weighed out in advance and just before use suspended in enough 2.5 per cent $\mathrm{NaHCO}_{3}$ to make an 8 per cent solution. This suspension was gently heated until solution was effected and, after being cooled to $38^{\circ} \mathrm{C}$, administered at once by slow intravenous injection.

2 After 42 instances with no reaction, a severe reaction was observed with a new lot of inulin. The difficulty has not been ascertained but is under investigation at the time of reading proof. 
The full routine of preparation and observation follows (in those instances in which all substances were not present there was little alteration in the procedure save for the omission of the xylose, creatinine or phlorizin, as the case may have been):

The subject was allowed no breakfast. During the two hours preceding the beginning of observations $2000 \mathrm{cc}$. of water were given by month. At zero hour 100 grams of xylose and 10 to 15 grams of creatinine were taken in 300 to $400 \mathrm{cc}$. of chilled water. The inulin infusion was started at 30 minutes and so regulated as to be completed in an additional 30 minutes. A catheter was inserted in the urethra at 80 minutes, and after a preliminary washout of the bladder with warm sterile water the first period of urine collection was started at 90 minutes. All subsequent urine collections were made by catheterization, with every care to empty the bladder completely.

The periods of urine collection varied from 10 to 20 minutes in duration and in number from 3 to 12 , depending upon the observations desired. When these observations were to include phlorizination, this was done after 3 control periods and followed by a 10 minute washout period after the injection of the phlorizin, and then 3 more periods of observation. Samples of blood were taken as close to the middle of the periods of urine collection as possible and interpolated exactly to that point, one blood sample being taken for each urine collection. In the long experiments $200 \mathrm{cc}$. of water each hour were sufficient to insure a high rate of urine flow, the ingestion of the water causing no apparent change in clearance.

\section{CHEMICAL METHODS}

Coagulation was prevented in the blood by the use of heparin. The blood was centrifuged as soon as drawn and precipitated immediately. Urine samples were diluted at once to the expected U/P ratio and precipitated at the termination of the experiment. Urea was determined by Van Slyke's (1927) manometric method and creatinine by the method used by Shannon, Jolliffe and Smith (1932). The ferric sulfate precipitation permits both creatinine and sugars to be done on the same filtrate. All analyses were done in duplicate, and if these did not agree a third set was run. The figures cited are an average of the duplicates, or of the closest two out of three determinations. Precipitation of plasma and diluted urine was effected in 1:5 or $1: 10$ dilution, as seemed advisable for accurate analysis. The method of Steiner, Urban and West (1932) was used, utilizing ferric sulfate followed by $\mathrm{BaCO}_{3}$. The barium in solution was subsequently precipitated by addition of 1 drop of saturated $\mathrm{Na}_{2} \mathrm{SO}_{4}$ to each 15 cc. of filtrate.

All sugar analyses were made by the Shaffer-Somogyi (1933) method, using Reagent Number 50 containing 5 grams of KI per liter. A variable quantity of filtrate was taken $(2$ to $5 \mathrm{cc}$.) depending upon the amount of sugar present, and water added to total $5 \mathrm{cc}$., to which were added $5 \mathrm{cc}$. of the copper reagent. Whenever possible enough filtrate was used to make the titration small, but not less than 1 cc. Two reagents were used, one having an iodate content equivalent to $17.5 \mathrm{cc}$. of $0.005 \mathrm{~N}$ thiosulfate, the other to $10.0 \mathrm{cc}$. of $0.005 \mathrm{~N}$ thiosulfate. Blanks were run with each set of sugar determinations, and standards were included every day. The correspondence between duplicates was excellent. Xylose was determined as reducing power after destruction of glucose by yeast. Glucose was removed from both plasma and urine filtrates by treatment with yeast, whether xylose was present or not. The supernatant fluid after the yeast is centrifuged out must be absolutely starch free, of course, for inulin determination. We have recently found Fleischmann's starch-free yeast very satisfactory. It can be procured in pound lots and keeps at least two weeks on ice. The tinfoil yeast contains as a binder, starch, which is very difficult to remove by washing. Inulin was hydrolyzed in the sugar tubes by adding $0.5 \mathrm{cc}$. of $\mathrm{N} \mathrm{H}_{2} \mathrm{SO}_{4}$ to $5.0 \mathrm{cc}$. of the iron filtrate, heating in a water bath for 15 minutes, cooling and neutralizing exactly to phenolphthalein with $\mathrm{N} \mathrm{KOH}$. Hydrolyzed in this manner, our sample of inulin has a glucose equivalent of 94 per cent; this reducing power is the same in aqueous solutions hydrolyzed directly, or when inulin is added to plasma or urine and precipitated as above, as evidenced by a series of 14 sets of simultaneous recoveries from water, plasma and urine at concentrations ranging from 50 to $500 \mathrm{mgm}$. per cent of inulin, both with and without the presence of known amounts of xylose. The maximum variation of plasma and urine from the aqueous solution was 2 per cent. Inulin in concentrations equivalent to $500 \mathrm{mgm}$. per cent in the plasma does not modify the color produced in the Jaffe reaction for creatinine if read within 15 minutes. The inulin concentration has been taken to be the difference between the total reducing power expressed as glucose before and after hydrolysis when xylose is present, or after hydrolysis alone in the absence of xylose. The latter procedure is justified since the saccharoid content of blood, using the above method, is of the order of magnitude of 1 to $2 \mathrm{mgm}$. per cent. Phlorizin has negligible reducing power and is not appreciably hydrolyzed by the treatment accorded inulin. Creatinine has a reducing power of 31 per cent of its weight in glucose equivalent by this method, either alone or in the presence of sugars, and appropriate corrections must be made. In the sugar determinations, corresponding plasmas and urines were handled simultaneously. All pipettes were specially constructed and standardized to blow out, and were cleaned in cleaning solution after each use. The smallest pipette used was $2.0 \mathrm{cc}$. We cannot place too much emphasis upon the need for precautions of this type in all sugar methods.

\section{RESULTS}

After intravenous injection, inulin is apparently quantitatively excreted in the urine in a period of 24 hours. Data on this point are given in the last column of Table I. Our data are complicated by 
TABLE I

Summary of observations on normal men

\begin{tabular}{|c|c|c|c|c|c|c|c|}
\hline 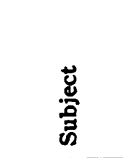 & 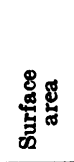 & 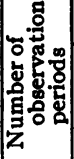 & 选 & 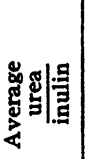 & 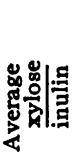 & 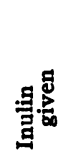 & 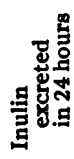 \\
\hline & $\begin{array}{l}\text { square } \\
\text { meters }\end{array}$ & \multirow{7}{*}{$\begin{array}{l}2 \\
4 \\
6 \\
4 \\
3 \\
6 \\
9 \\
3 \\
9 \\
3 \\
3\end{array}$} & \multirow{7}{*}{$\begin{array}{r}142 \\
129 \\
141 \\
93 \\
84 \\
82 \\
72 \\
76 \\
110 \\
123 \\
128\end{array}$} & \multirow[b]{2}{*}{$\begin{array}{l}0.65 \\
0.59\end{array}$} & \multirow{3}{*}{$\begin{array}{l}0.80 \\
0.82 \\
0.71 \\
0.81 \\
0.81 \\
0.78 \\
0.79\end{array}$} & \multirow{2}{*}{$\begin{array}{c}\text { grams } \\
160\end{array}$} & \multirow{2}{*}{$\begin{array}{r}\text { per } \\
\text { cent } \\
92\end{array}$} \\
\hline $\begin{array}{l}\text { J. A. S.. } \\
\text { M. C... } \\
\text { R. S. . } \\
\text { B. R... }\end{array}$ & $\begin{array}{l}2.10 \\
2.08 \\
1.75 \\
1.67\end{array}$ & & & & & & \\
\hline W. F... & 1.69 & & & 0.67 & & \multirow[t]{2}{*}{$\begin{array}{l}100 \\
100 \\
100 \\
100\end{array}$} & $\begin{array}{l}95 \\
97 \\
98\end{array}$ \\
\hline & & & & 0.65 & 0.80 & & 103 \\
\hline $\mathrm{S}_{\mathrm{S} .}^{\mathrm{C} .}$ & 1.63 & & & 62 & $\begin{array}{r}0.76 \\
0.72\end{array}$ & & \\
\hline & & & & & 0.79 & & \\
\hline Average & & & & 0.635 & 0.78 & & 97 \\
\hline
\end{tabular}

the fact that facilities were not available at the time of these observations to insure the complete injection of an exact quantity of inulin; there was always a slight loss at the beginning of the injec- tion in clearing the infusion apparatus of air, and again at the termination of the injection when some of the solution is necessarily lost through wetting the gravity bottle and the small quantities remaining in the connecting tube. This loss was not taken into account in our figures, but a 2 per cent correction would probably suffice. Our 24 hour urines show, however, that the recovery of inulin is essentially complete. In two instances not recorded in Table I, we recovered 95 and 98 per cent.

It could be demonstrated that the clearance of inulin is independent of plasma level from observations designed to answer other questions, but in certain instances (Figure 1) we have examined this point particularly. The data in Figure 1 show that the renal excretion of inulin is directly proportional to the plasma level (i.e., the clearance is constant) over a fourfold change of the latter. This question has not been examined at plasma levels below $50 \mathrm{mgm}$. per cent, but that this linear relationship obtains throughout the range from 0

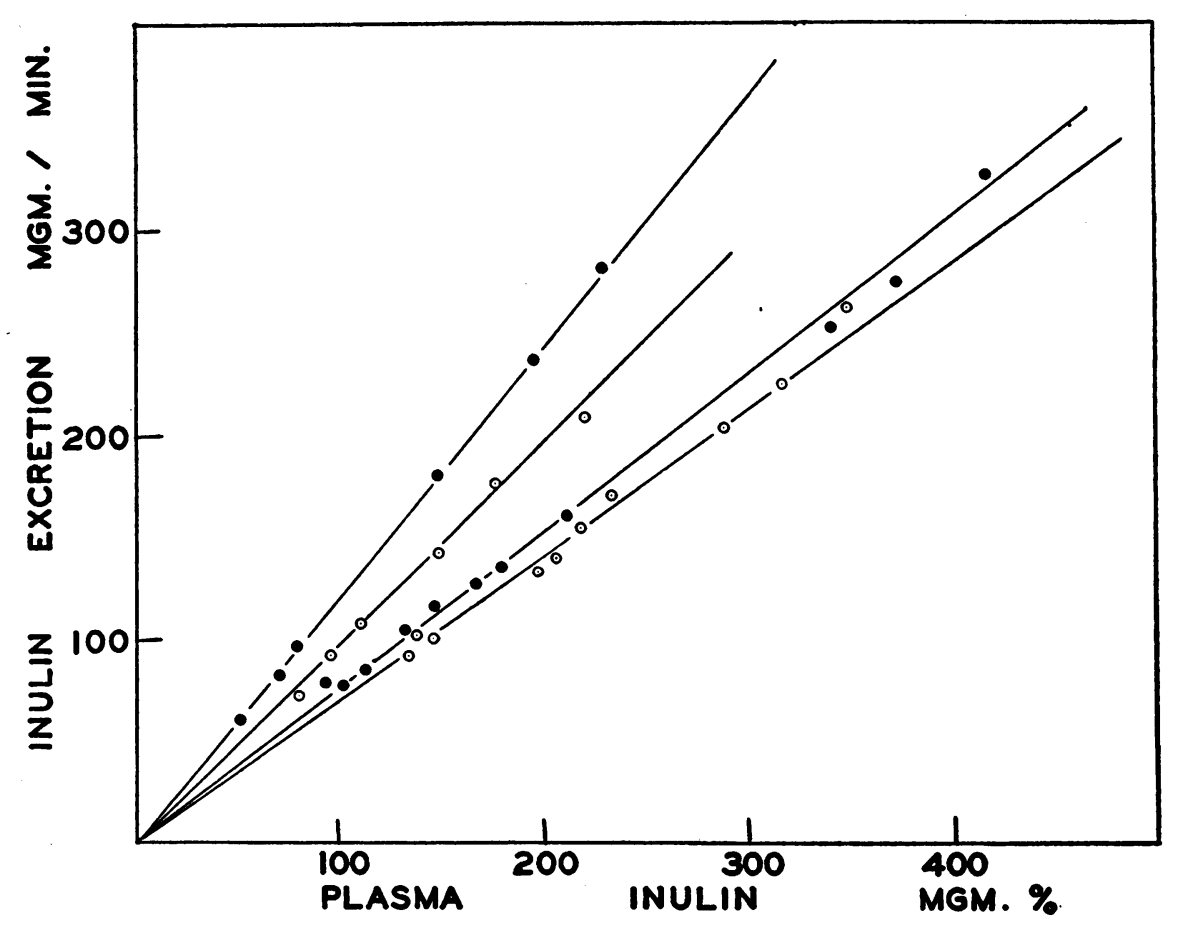

Fig. 1. Data on Four Experiments at Various Clearance Levels Showing that the Rate of Inulin Excretion Is Proportional to the Plasma Concentration.

Each point is a single clearance period. The solid dots and open circles indicate alternate experiments each of which is indicated by a straight line. 
to $50 \mathrm{mgm}$. per cent in the plasma is indicated by the fact that the straight lines generated at higher plasma levels extrapolate to the intersection of the coordinates. (The rate of fall of the plasma concentration of inulin is, after the first $40 \mathrm{~min}$ utes from the end of the infusion, exponentially related to time. This is a necessary consequence when the rate of removal from the blood is a linear function of the plasma level, but it reveals nothing about the mechanism or mechanisms involved in this process.)

Table I shows that the clearance of xylose in normal man is less than the clearance of inulin by an average of 22 per cent, while the creatinine clearance in our observations bears essentially the same relationship to xylose as has been described by Jolliffe and Chasis (1933). Although the creatinine data must be deferred to a subsequent paper, we may note here that at plasma levels of creatinine from 5 to $10 \mathrm{mgm}$. per cent the creatinine clearance exceeds the inulin clearance by 30 to 45 per cent. This corresponds to a creatinine/xylose clearance ratio of 1.67 to 1.86 , as compared to the average figure of Jolliffe and Chasis of 1.73. Our urea/xylose clearance ratios are higher than were observed by these authors, but our series is smaller.

The relationship between xylose and inulin clearances in normal man require special comment. It will appear from Table I that this ratio varies somewhat from one subject to another, although in a single individual the variation is slight (see Figure 2). The data upon which Figure 2 is based were obtained from one man (W. F.) over a period of 6 weeks. The mean xylose/inulin clearance ratio in this individual is 0.78 , with a maximum variation of \pm 0.04 . It can be seen from Figure 2 that this ratio is not dependent upon the $U / P$ ratio over the range examined ( 6 to 30 ), but it must be noted that the highest $U / P$ ratio $(30)$ was obtained at a urine flow of above $2 \mathrm{cc}$. per minute. No attempt has been made to examine this ratio over lower ranges of urine flow.

Chasis, Jolliffe and Smith (1933) found that less than $65 \mathrm{mgm}$. of phlorizin were required to bring the glucose clearance up to the xylose clearance, but for reasons to be discussed in a subsequent paper, we increased this dose to $100 \mathrm{mgm}$.

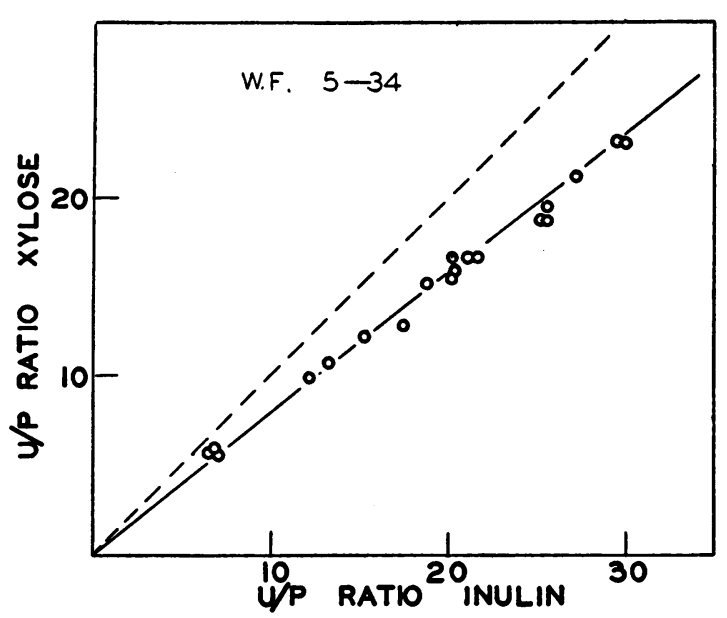

Fig. 2. Data on One Individual Showing That the Xylose U/P Ratio (and Therefore the Clearance) Is Less Than the Simultaneous Inulin Clearance.

The average xylose/inulin clearance ratio in this individual was 0.78 , and showed little variation over a period of six weeks. The broken line indicates a slope of 1.00 . Each point is based on a single pair of simultaneous inulin and xylose clearances.

per kilogram. (This dose was taken by J. A. S. in a preliminary trial.) Detailed results of our observations before and after phlorizin are given for a single individual in Table II, and a summary of observations on five individuals is given in Table III. When phlorizin is administered in doses of $100 \mathrm{mgm}$. per kilogram the glucose/ inulin clearance ratio is raised from 0 . to 0.91 , and the xylose/inulin clearance ratio from an average of 0.79 to 0.89 . The urea/inulin clearance ratio is not changed ( 0.62 before, and 0.62 after phlorizin). As was previously shown by Chasis, Jolliffe and Smith (1933) the glucose clearance rises to, but does not significantly exceed, the xylose clearance. The above authors found the same urea/xylose clearance ratio before and after phlorizin, whereas we find a slight decrease (from 0.78 to 0.70 ). It should be noted, however, that the clearances of all the substances fall to a variable degree after the administration of phlorizin, and in view of this fact it is difficult to evaluate the significance of the change in the urea/xylose clearance ratio.

In Table IV we have included data to show that the intravenous infusion of inulin to man has no effect upon the xylose or urea clearances. This 
TABLE II

Observations on W. F. before and after phlorisin. May 20, 1934

\begin{tabular}{|c|c|c|c|c|c|c|c|c|c|c|c|c|c|c|}
\hline \multirow{2}{*}{ 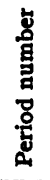 } & \multirow[b]{2}{*}{ 苛 } & \multirow[b]{2}{*}{ 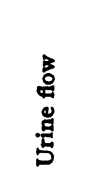 } & \multicolumn{4}{|c|}{ Plasma level } & \multicolumn{4}{|c|}{ Clearance } & \multicolumn{4}{|c|}{ Clearance ratios } \\
\hline & & & వొ & 总 & 量 & 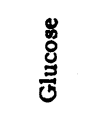 & వే & 兽 & 点 & $\begin{array}{l}\mathscr{\%} \\
\stackrel{\Xi}{3}\end{array}$ & 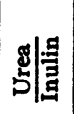 & 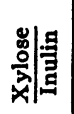 & 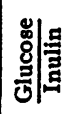 & | \\
\hline & $\underset{\text { min- }}{\text { mines }}$ & $\begin{array}{l}\text { cc. per } \\
\text { minute }\end{array}$ & $\underset{\text { per cent }}{\operatorname{mgm} .}$ & $\underset{\text { per cent }}{\operatorname{mgm} .}$ & $\underset{\text { per cent }}{\operatorname{mgm} .}$ & $\underset{\text { per cent }}{\operatorname{mgm} .}$ & $\begin{array}{l}\text { cc. per } \\
\text { minute }\end{array}$ & $\begin{array}{l}\text { cc.per } \\
\text { minute }\end{array}$ & $\begin{array}{l}\text { cc. per } \\
\text { minute }\end{array}$ & $\begin{array}{l}c c . \text { per } \\
\text { minute }\end{array}$ & & & & \\
\hline $\begin{array}{l}4 \\
5 \\
6\end{array}$ & $\begin{array}{l}11 \\
11 \\
10\end{array}$ & $\begin{array}{l}4.5 \\
4.2 \\
4.1\end{array}$ & $\begin{array}{l}29.3 \\
29.0 \\
28.7\end{array}$ & $\begin{array}{l}86.2 \\
87.3 \\
85.5\end{array}$ & $\begin{array}{l}214 \\
199 \\
187\end{array}$ & $\begin{array}{l}103 \\
102 \\
100\end{array}$ & $\begin{array}{l}36.4 \\
35.3 \\
35.1\end{array}$ & $\begin{array}{l}\mathbf{5 3 . 6} \\
\mathbf{5 0 . 0} \\
\mathbf{5 0 . 9}\end{array}$ & $\begin{array}{l}\mathbf{5 7 . 1} \\
\mathbf{5 6 . 7} \\
\mathbf{5 5 . 0}\end{array}$ & $\begin{array}{l}51.3 \\
50.8 \\
49.0\end{array}$ & $\begin{array}{l}0.64 \\
0.62 \\
0.64\end{array}$ & $\begin{array}{l}0.94 \\
0.88 \\
0.92\end{array}$ & $\begin{array}{l}0.90 \\
0.90 \\
0.89\end{array}$ & $\begin{array}{l}0.96 \\
1.02 \\
0.96\end{array}$ \\
\hline
\end{tabular}

TABLE III

Summary of experiments on phlorisinised man

\begin{tabular}{|c|c|c|c|c|c|c|c|c|c|c|}
\hline \multicolumn{5}{|c|}{ Before phlorizin } & \multicolumn{6}{|c|}{ After phlorizin } \\
\hline \multirow{2}{*}{ Subject } & \multirow{2}{*}{$\begin{array}{l}\text { Num- } \\
\text { ber of } \\
\text { pe- } \\
\text { riods }\end{array}$} & \multirow{2}{*}{$\begin{array}{l}\text { Average } \\
\text { inulin } \\
\text { clearance }\end{array}$} & \multicolumn{2}{|c|}{$\begin{array}{l}\text { Average clearance } \\
\text { ratios }\end{array}$} & \multirow{2}{*}{$\begin{array}{l}\text { Num- } \\
\text { ber of } \\
\text { pe-- } \\
\text { riods }\end{array}$} & \multirow{2}{*}{$\begin{array}{l}\text { Per cent change in } \\
\text { inulin clearance }\end{array}$} & \multicolumn{4}{|c|}{$\begin{array}{c}\text { Average } \\
\text { ratios }\end{array}$} \\
\hline & & & $\frac{\text { Urea }}{\text { Inulin }}$ & $\frac{\text { Xylose }}{\text { Inulin }}$ & & & $\frac{\text { Urea }}{\text { Inulin }}$ & $\frac{\text { Xylose }}{\text { Inulin }}$ & $\frac{\text { Glucose }}{\text { Inulin }}$ & $\frac{\text { Glucose }}{\text { Xylose }}$ \\
\hline $\begin{array}{l}\text { J.A. } \\
\text { B. R. }\end{array} \ldots \ldots \ldots \ldots$ & $\begin{array}{l}2 \\
3\end{array}$ & $\begin{array}{r}142 \\
85\end{array}$ & $\begin{array}{l}0.65 \\
0.67\end{array}$ & $\begin{array}{l}0.80 \\
0.82\end{array}$ & $\begin{array}{l}3 \\
3\end{array}$ & $\begin{array}{l}-4.0 \\
-17.0\end{array}$ & $\begin{array}{l}0.63 \\
0.68\end{array}$ & $\begin{array}{l}0.90 \\
0.89\end{array}$ & $\begin{array}{l}0.97 \\
0.89\end{array}$ & 1.08 \\
\hline $\begin{array}{l}\text { W. F } \ldots \ldots \ldots \ldots \\
\text { J. C } \ldots \ldots \ldots \ldots\end{array}$ & $\begin{array}{l}3 \\
3\end{array}$ & $\begin{array}{r}76 \\
112\end{array}$ & 0.65 & 0.80 & $\begin{array}{l}3 \\
3\end{array}$ & $\begin{array}{l}-32.0 \\
-11.0\end{array}$ & 0.63 & $\begin{array}{l}0.91 \\
0.92\end{array}$ & 0.90 & 0.99 \\
\hline 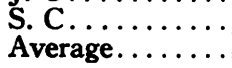 & 3 & 123 & $\begin{array}{l}0.51 \\
0.62\end{array}$ & $\begin{array}{l}0.73 \\
0.79\end{array}$ & 3 & $\begin{array}{l}-45.0 \\
-20.6\end{array}$ & $\begin{array}{l}0.53 \\
0.62\end{array}$ & $\begin{array}{l}0.86 \\
0.89\end{array}$ & $\begin{array}{l}0.83 \\
0.91\end{array}$ & $\begin{array}{l}0.94 \\
1.01\end{array}$ \\
\hline
\end{tabular}

TABLE IV

Absence of effect of inulin infusion upon other clearances

\begin{tabular}{|c|c|c|c|c|c|c|c|c|c|c|c|}
\hline \multirow{2}{*}{ 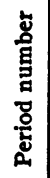 } & \multirow{2}{*}{ 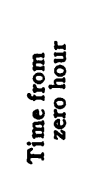 } & \multirow{2}{*}{ 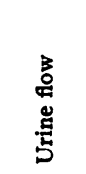 } & \multicolumn{3}{|c|}{ Plasma level } & \multicolumn{3}{|c|}{ Clearances } & \multicolumn{3}{|c|}{ Clearance ratios } \\
\hline & & & \$ే & $\frac{\mathscr{y}}{\grave{\lambda}}$ & 吕 & $\$$ & $\frac{\mathscr{0}}{\grave{x}}$ & 呆 & $5 \mid$ & $\$$ & 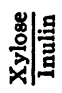 \\
\hline & minutes & $\begin{array}{l}c c \text { per } \\
\text { minute }\end{array}$ & $\underset{\text { per cent }}{m g m .}$ & $\underset{\text { per cent }}{\operatorname{mgm} .}$ & $\begin{array}{l}\text { mgm. } \\
\text { per cent }\end{array}$ & $\begin{array}{l}\text { cc. per } \\
\text { minute }\end{array}$ & $\begin{array}{l}c c \text { c. per } \\
\text { minute }\end{array}$ & $\begin{array}{l}c c \text {. per } \\
\text { minute }\end{array}$ & & & \\
\hline $\begin{array}{l}1 \\
2\end{array}$ & $\begin{array}{l}132 \\
149 \\
159\end{array}$ & $\begin{array}{l}9.4 \\
7.5\end{array}$ & $\begin{array}{l}29.7 \\
29.8\end{array}$ & $\begin{array}{l}73.7 \\
81.5\end{array}$ & & $\begin{array}{l}50.9 \\
54.6\end{array}$ & $\begin{array}{l}66.5 \\
71.1\end{array}$ & & $\begin{array}{l}0.76 \\
0.77\end{array}$ & & \\
\hline 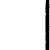 & & & & & infusion & e note & & & & & \\
\hline $\begin{array}{l}3 \\
4 \\
5\end{array}$ & $\begin{array}{l}350 \\
404 \\
419\end{array}$ & $\begin{array}{l}6.5 \\
6.0 \\
5.6\end{array}$ & $\begin{array}{l}27.4 \\
27.5 \\
27.6\end{array}$ & $\begin{array}{l}122.7 \\
119.3 \\
122.3\end{array}$ & $\begin{array}{l}335 \\
242 \\
252\end{array}$ & $\begin{array}{l}57.4 \\
54.3 \\
56.0\end{array}$ & $\begin{array}{l}70.2 \\
69.1 \\
69.0\end{array}$ & $\begin{array}{l}82.6 \\
82.9 \\
86.9\end{array}$ & $\begin{array}{l}0.82 \\
0.80 \\
0.81\end{array}$ & $\begin{array}{l}0.70 \\
0.66 \\
0.64\end{array}$ & $\begin{array}{l}0.85 \\
0.83 \\
0.79\end{array}$ \\
\hline
\end{tabular}

Note: 100 grams inulin in $500 \mathrm{cc}$. of 0.6 per cent saline were given at the termination of Period 2 (from 210 to 240 minutes). At 250 minutes 25 grams xylose were given by mouth. At 333 minutes the bladder was washed out and the third period started at 338 minutes. 
carbohydrate appears to be just as physiologically inert as are xylose and sucrose (Jolliffe, Shannon and Smith (1932b)).

\section{DISCUSSION}

No doubt the most noteworthy of these observations is the fact that the inulin clearance exceeds the simultaneous xylose clearance in normal man. In this we confirm the findings of Richards, Westfall and Bott (1934) in the dog. This disparity is open to three interpretations (see also Shannon (1934b)) :

(a) The xylose clearance constitutes a measure of glomerular filtration, and inulin is in part excreted by the process of tubular secretion; $(b)$ the inulin clearance is a measure of glomerular filtration and xylose is reabsorbed; $(c)$ the level of glomerular filtration is above that of the inulin clearance.

The possibility that the level of glomerular filtration lies below the level of the xylose clearance (i.e., that xylose is secreted) is presumptively ruled out by the evidence reviewed in the first part of the paper (an argument originally advanced by Jolliffe, Shannon and Smith (1932b)).

The aglomerular kidney of both Lophius piscatorius and Opsanus tau (Richards, Westfall and Bott (1934) ; Shannon (1934b)) is incapable of secreting inulin. Since we hesitate to argue from the fish to the mammalian kidney, there remains the necessity of adducing independent evidence that the disparity between the inulin and xylose clearance is not due to secretion of the inulin. Evidence on this point is, we think, available in the facts that the amount of inulin excreted per unit of time is linearly related to the plasma level, and that the curves relating these terms extrapolate to the intersection of the coordinates. We previously deemed that this linear relationship did not necessarily exclude secretion (Shannon, Jolliffe and Smith (1932)), because we believed it possible that a secretory mechanism might be able to handle a substance in direct proportion to the plasma concentration. On reconsideration, however, we note that those substances for which there is independent evidence of secretion are found, in fact, to show a curvilinear relationship, i.e., phenol red in dog (Marshall and Vickers (1923) ; Marshall (1931)), frog (Marshall and
Crane (1924)), toadfish (Marshall and Grafflin (1932) ; Bieter (1933)) ; creatinine in the toadfish (Marshall and Grafflin (1932)), dogfish (Shannon (1934a, 1934b)), and in man according to evidence to be presented later. In theory, it would seem that any process of secretion, involving as it does the expenditure of energy in work, might be diminished, relative to the plasma level, at high 'plasma concentrations, and consequently that the amount excreted per unit time would be related to the plasma level in a curvilinear manner (Shannon (1934a)). A possible exception to this argument might occur in the instance of $(a)$ a substance that is partly secreted, but of such a nature that a constant fraction of blood going to the kidney is actually completely cleared of it, and (b) a substance of such a nature that at high plasma levels the secreted portion is quantitatively negligible in comparison with the quantity excreted by filtration. In both these cases the amount excreted will be linearly related to the plasma level, and extrapolation from high plasma levels will lead to the zero axis. It is, of course, impossible to exclude inulin from one of the above classes, because we have no knowledge of what constitutes a high or low plasma level in relation to the cells that might be capable of secreting it. But the inulin clearance has been studied over ranges of plasma level from 50 to $400 \mathrm{mgm}$. per cent, and in view of the linear relationship existing here it would appear that if there is any secretion, the secreted moiety is small.

Although no single line of evidence is so complete as to establish proof, the fact of the linear relation between plasma level and rate of excretion, coupled with the inability of the aglomerular kidney to secrete inulin and the evidence against secretion of carbohydrates in general by the mammals, as reviewed at the opening of this paper, encourages us to proceed on the assumption that inulin is not secreted in man, and that of the above possibilities ( $a$ ) can be eliminated. There is, then, no other alternative but to suppose $(b)$ that the inulin clearance constitutes a measure of glomerular filtration, or (c) that the level of glomerular filtration lies somewhere above the level of the inulin clearance.

In either case it follows that a significant portion of the xylose is reabsorbed from the glomerular filtrate during its passage down the tu- 
bules, the exact quantity being undeterminable until there is a selection between alternatives stated above $(b$ or $c)$. (These investigations have not included sucrose, but since the xylose and sucrose clearances are so nearly equal in man there is probably some reabsorption of the latter as well.) The alteration of the xylose clearance toward that of inulin ( 0.79 to 0.89$)$ under the influence of phlorizin seems to indicate that, in part at least, this reabsorption is an active one in the same sense as is that of glucose in the normal kidney. The absence of complete identity between the xylose and inulin clearances after phlorizin may, in this view, indicate the passive diffusion of a small amount of xylose from the tubular urine into the blood or lymph. This possibility is supported by the fact that the glucose clearance agrees with the xylose rather than with the inulin clearance. If this interpretation is accepted, it can be inferred that the passive diffusion of inulin (molecular weight $=972$ or more) is small, since the clearances of the much more diffusible xylose and glucose (molecular weight $=150$ and 180) after phlorizin are only 10 per cent lower than that of inulin. If the molecular weight of inulin is greater than 972 , this argument is all the more effective.

It was suggested in $(c)$ that there might be some active reabsorption of inulin. Even if this reabsorption were blocked by phlorizin it would be obscured by the general fall in clearances and therefore would not be revealed without an independent standard of reference. And having uncovered in these observations, and in observations on the dogfish, an active reabsorption of xylose, it becomes necessary to rule out the possibility of the active reabsorption of inulin by further evidence before it can be accepted that the inulin clearance is a measure of glomerular filtration. The constancy of the urea/inulin clearance ratio (or the lowering of the urea/xylose clearance ratio) before and after phlorizin in our data would indicate that this drug affects the xylose rather than the inulin clearance, but since the relative change in these clearances is so small, and since there is a significant fall in all the clearances after phlorizin, this argument is dubious. Observations made since the work of Jolliffe, Shannon and Smith (1932a) have shown that the urea/ xylose clearance ratio may be altered unpre- dictably by changes in absolute clearance, and perhaps by other factors.

Further evidence against the possible active reabsorption of inulin will be presented in a subsequent paper.

\section{SUMMARY}

1. The excretion of the polysaccharide inulin (the molecular weight of which is variously given as 972 to 4860 ) has been examined in man after intravenous infusion, and the inulin clearance has been compared with simultaneous urea, glucose and xylose clearances in both normal and phlorizinized man.

2. The inulin clearance in normal man is independent of the plasma concentration, and the curves relating plasma concentration to quantity excreted per unit time extrapolate to zero coordinates.

3. This fact, combined with the fact that inulin is not secreted by the aglomerular fish and with other evidence indicating that the mammalian kidney cannot secrete carbohydrates in general, supports the tentative conclusion that inulin is not secreted by the renal tubules in man.

4. The inulin clearance exceeds the simultaneous xylose clearance in normal man by an average of 22 per cent.

5. In the light of (3) it follows that some xylose (and sucrose) is normally reabsorbed by the renal tubules from the glomerular filtrate; this reabsorption is in part an active process, since the disparity between the inulin and xylose clearances is in part removed by phlorizin; that fraction of the disparity (10 per cent) which is not removed by phlorizin may be due to passive diffusion of the xylose from the tubular urine back into the blood or lymph.

6. It seems scarcely probable that in the normal kidney there is any significant diffusion of inulin, even accepting a molecular weight as low as 972 , but in view of the fact that evidence has been uncovered for the active reabsorption of xylose, evidence against the active reabsorption of inulin should be obtained before the inulin clearance is accepted as a measure of glomerular filtration.

We wish to express our indebtedness to the Department of Medicine for the services of the 
Third (New York University) Medical Division of Bellevue Hospital.

\section{BIBLIOGRAPHY}

Bieter, R. N., Excretion of phenol red by the aglomerular kidney. Proc. Soc. Exper. Biol. and Med., 1933, 30, 981.

Chasis, H., Jolliffe, N., and Smith, H. W., The action of phlorizin on the excretion of glucose, xylose, sucrose, creatinine and urea by man. J. Clin. Invest., 1933, 12, 1083.

Clarke, R. W., and Smith, H. W., Absorption and excretion of water and salts by the elasmobranch fishes. III. The use of xylose as a measure of the glomerular filtrate in Squalus acanthias. J. Cell. and Comp. Physiol., 1932, 1, 131.

Cope, C. L., The excretion of non-metabolized sugars by the mammalian kidney. J. Physiol., 1933, 80, 238.

Deuel, H. J., Jr., and Chambers, W. H., The rate of elimination of ingested sugars in phlorizin diabetes. J. Biol. Chem., 1925, 65, 7.

Drew, H. D. K., and Haworth, W. N., Polysaccharides. III. The molecular complexity of inulin. J. Chem. Soc., 1928, 2690.

Haworth, W. N., Hirst, E. L., and Percival, E. G. V., Polysaccharides. XV. The molecular structure of inulin. J. Chem. Soc., 1932, 2384.

Irvine, J. C., and Montgomery, T. N., The methylation and constitution of inulin. J. Am. Chem. Soc., 1933, 55, 1988.

Jolliffe, N., The excretion of xylose by glomerular and aglomerular kidneys. Proc. Soc. Exper. Biol. and Med., 1930, 28, 5.

Jolliffe, N., and Chasis, H., The filtration and secretion of exogenous creatinine in man. Am. J. Physiol., 1933, 104, 677.

Jolliffe, N., Shannon, J. A., and Smith, H. W., The excretion of urine in the dog. III. The use of nonmetabolized sugars in the measurement of the glomerular filtrate. Am. J. Physiol,, 1932a, 100, 301.

Jolliffe, N., Shannon, J. A., and Smith, H. W., The excretion of urine in the dog. V. The effects of xylose and sucrose upon the glomerular and urea clearances. Am. J. Physiol., 1932b, 101, 639.

Keith, N. M., Power, M. H., and Peterson, R. D., The renal excretion of sucrose, xylose, urea and inorganic sulphate in normal men: a comparison of simultaneous clearances. Proc. Staff Meet. Mayo Clin., 1933, 8, 682.

Marshall, E. K., Jr., A comparison of the function of the glomerular and aglomerular kidney. Am. J. Physiol., 1930, 94, 1.
Marshall, E. K., Jr., The secretion of phenol red by the mammalian kidney. Am. J. Physiol., 1931, 99, 77.

Marshall, E. K., Jr., The comparative physiology of the kidney in relation to theories of renal secretion. Physiol. Rev., 1934, 14, 133.

Marshall, E. K., Jr., and Crane, M. M., The secretory function of the renal tubules. Am. J. Physiol., 1924, 70, 465.

Marshall, E. K., Jr., and Grafflin, A. L., The function of the proximal convoluted segment of the renal tubule. J. Cell. and Comp. Physiol., 1932, 1, 161.

Marshall, E. K., Jr., and Vickers, J. L., The mechanism of the elimination of phenolsulphonephthalein by the kidney-a proof of secretion by the convoluted tubules. Bull. Johns Hopkins Hospital, 1923, 34, 1.

Pitts, R. F., The excretion of urine in the dog. VII. Inorganic phosphate in relation to plasma phosphate level. Am. J. Physiol., 1933, 106, 1.

Pitts, R. F., The clearance of creatine in the phlorizinized dog. Am. J. Physiol., 1934, 109, 542.

Pringsheim, H., The Chemistry of the Monosaccharides and the Polysaccharides. McGraw-Hill Book Company, New York, 1932.

Richards, A. N., Westfall, B. B., and Bott, P. A., Renal excretion of inulin, creatinine and xylose in normal dogs. Proc. Soc. Exper. Biol. and Med., 1934, 32, 73.

Shaffer, P. A., and Somogyi, M., Copper-iodometric reagents for sugar determination. J. Biol. Chem., 1933, 100, 695.

Shannon, J. A., Absorption and excretion of water and salts by the elasmobranch fishes. IV. The secretion of exogenous creatinine by the dogfish, Squalus acanthias. J. Cell. and Comp. Physiol., 1934a, 4, 211.

Shannon, J. A., The excretion of inulin by the dogfish, Squalus acanthias. J. Cell. and Comp. Physiol., 1934b, 5, 301.

Shannon, J. A., Jolliffe, N., and Smith, H. W., The excretion of urine in the dog. VI. The filtration and secretion of exogenous creatinine. Am. J. Physiol., 1932, 102, 534.

Smith, H. W., The Kidney in Health and Disease. Edited by Berglund and Medes, Lea and Febiger, Philadelphia (In press), 1935.

Steiner, A., Urban, F., and West, E. S., Iron and thorium precipitation of biological fluids for sugar and other analyses. J. Biol. Chem., 1932, 98, 289.

White, H. L., and Monaghan, B., A comparison of the clearances of creatinine and of various sugars. Am. J. Physiol., 1933, 106, 16.

Van Slyke, D. D., Determination of urea by gasometric measurement of the carbon dioxide formed by the action of urease. J. Biol. Chem., 1927, 73, 695. 